\title{
CILIA OF A DISTINCTIVE STRUCTURE $(9+\circ)$ IN ENDOCRINE AND OTHER TISSUES
}

\author{
A. R. Currie, B.SC., F.R.C.P. (Ed in. and Glas.), F.C.Path., F.R.S.E. \\ D. N. Wheatley, B.Sc., Ph.D., M.I.Biol. \\ Department of Pathology, University Medical \\ Buildings, Foresterhill, Aberdeen.
}

Cilia or flagella control and effect the movement of many unicellular organisms, for example Paramecium; they may also cause movement of the medium surrounding cells as in flame cells of Platyhelminthes and in the epithelium of the respiratory tract and fallopian tubes in the human subject. The fine structure of these cilia is well known and is essentially the same from the lowest ciliated creature to the highest mammals (for a brief review see Grimstone, 1962).

The cilia are characterized by a $9+2$ fibre pattern (Fig. 1) and a single basal body; the basal body, which has been referred to variously as the kinetoplast, kinetosome, centrosome, basal granule, basal corpuscle etc., has a very characteristic structure identical with that of the cen'triole (Fig. 2).

Recent work on ciliary movement has led to the following hypotheses: the peripheral fibre pairs are probably contractile, whilst the central pair may be structural supports that determine the plane in which a cilium moves (Gibbons, 1961; Afzelius 1962,); secondary fibres or sidearms may possess the contractile fibrous proteins which move a cilium (André, 1961).

From time to time brief reports on "aberrant" forms of cilia have been published (Pitelka, 1962; Satir, 1962). It is now established, however, that there is a distinctive ciliary type with a fibre pattern of $9+0$, in contrast to the usual $9+2$ form, and it has been found in cells of many different organs. When $9+0$ cilia are found there is generally only one in a cell, whilst in mammalian tissue such as the tracheal epithelium there are numerous $9+2$ cilia in each cell.

These cilia have been found in invertebrates, for example in Myzostomum sperms (Afzelius, 1962 ), in the plate organs of the honey-bee antenna (Slifer and Sekhon, 1961), in the locust ear (Gray, 1960), and in sense cells of Pecten (Miller, 1958) and crab (Whitear, 1960). They have been more frequently reported, however, in vertebrate tissues-particularly mammalianbut this may be due to the fact that these tissues have been more intensively studied with the electron microscope (Table 1).

\section{Structure of $9+0$ cilia}

$9+0$ cilia in mammalian tissues differ from the $9+2$ form in that they are associated with a diplosome - that is a pair of centrioles, one usually lying at right angles to the other. The fine structure of the cilium, in longitudinal and transverse section, is illustrated diagrammatically in Fig. 3.

Our studies of these cilia in the zona glomerulosa of the rat adrenal cortex (Wheatley, 1966a) have confirmed much of the earlier reports. The cilium (Fig. 4) is a solitary organelle; its basal body (referred to as the distal centriole by Barnes, 1961) and associated centriole (or proximal centriole) lie close to the nucleus. The Golgi zone is seen nearby. The wall of the proximal centriole (in transverse section

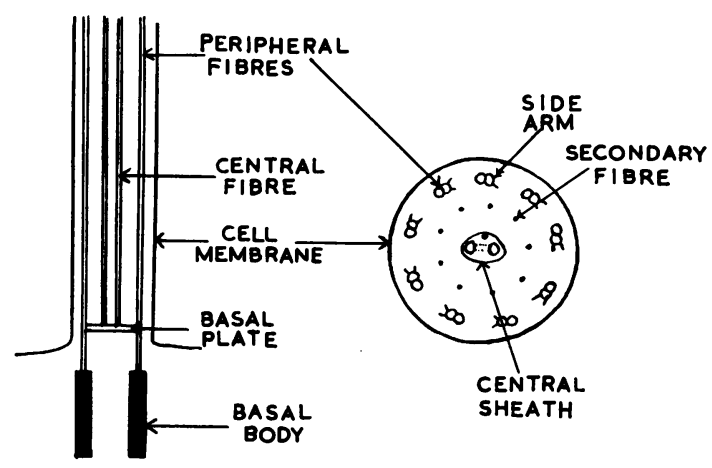

Fig. 1. Diagrammatic L.S. and T.S. of a $9+2$ cilium 


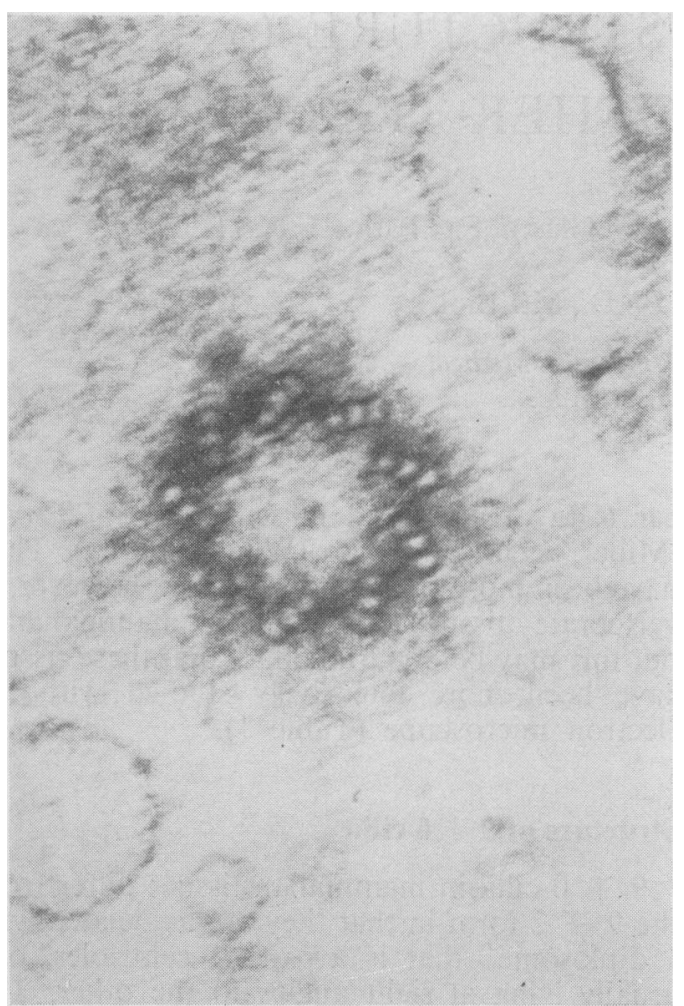

Fig. 2 T.S. of a centriole or basal body in a cell of the rat adrenal zona glomerulosa. $\times 140,000$. All electron micrographs are of lead contrasted ultrathin sections of $\mathrm{OsO}_{4}$-fixed, Epon 8:12-embedded tissue.

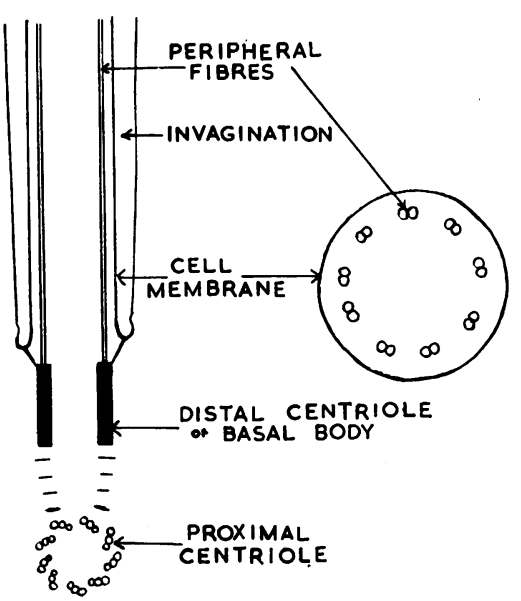

Fig. 3. Diagrammatic L.S. and T.S. of a $9+0$, diplosome-associated cilium

in Fig. 4) consists of nine bundles, each of which has three fibrous elements. Banded filaments radiate from the two bundles that lie closest to the distal centriole: the bands are spaced at intervals of about $550 \mathrm{~A}$. The distal centriole or basal body (in longitudinal section in Figo 4), is about $330 \mathrm{~m} \mu$ in length. From it paracen trioles or satellites arise; cytoplasmic micro tubules, or spindle fibres, are often attached to these processes. The basal body is linked to the cell membrane by pnocesses, similar in structure

TABLE 1

Summary of Previous Reports on Mammaliam Tissues With $9+0$ or Diplosome-Associated Cilia

\begin{tabular}{|c|c|c|}
\hline Tissue & Species & Reference \\
\hline $\begin{array}{l}\text { Adrenal medulla } \\
\text { Pancreas (endocr:ne) } \\
\text { Parathyroids } \\
\text { Rete testis } \\
\text { Cerebral cortex } \\
\text { Retina } \\
\text { Autonomic nervous system } \\
\text { Kidney } \\
\text { Skin } \\
\text { Spleen } \\
\text { Endothelial cells of } \\
\text { trabeculum of eye } \\
\text { Fibroblasts and } \\
\text { smooth muscle cells }\end{array}$ & $\begin{array}{l}\text { Mouse } \\
\text { Rabibit } \\
\text { Rat } \\
\text { Dog } \\
\text { Human foetus } \\
\text { Rat } \\
\text { Mouse ( } \alpha \text { cells }) \\
\text { Man ( } \beta \text { cells) } \\
\text { Virginia Deer } \\
\text { Rat } \\
\text { Rat } \\
\text { Mouse } \\
\text { Various mammals } \\
\text { Guinea-pig } \\
\text { Rat } \\
\text { Rat } \\
\text { Man } \\
\text { Human foetus } \\
\text { Man } \\
\text { Rat }\end{array}$ & $\begin{array}{l}\text { Barnes (1961) } \\
\text { Salazar (1963) } \\
\text { Maillard (1963) } \\
\text { Kagayama (1965) } \\
\text { Ellis (1966) } \\
\text { de Robentis et al. (1960) } \\
\text { Coupland (1965) } \\
\text { Munger (1958) } \\
\text { Eisterhuizen and Lever (1961) } \\
\text { Munger and Roth (1963) } \\
\text { Leeson (1962) } \\
\text { Dahl (1963) } \\
\text { de Robertis (1956) } \\
\text { Tokayasu and Yamada (1959) } \\
\text { Allen (1965) } \\
\text { Grillo and Palay (1963) } \\
\text { Latta et al. (1961) } \\
\text { Wilson and McWhorter (1963) } \\
\text { Zamboni and Westin (1964) } \\
\text { Vegge (1963) } \\
\text { Sorokin (1962) }\end{array}$ \\
\hline
\end{tabular}




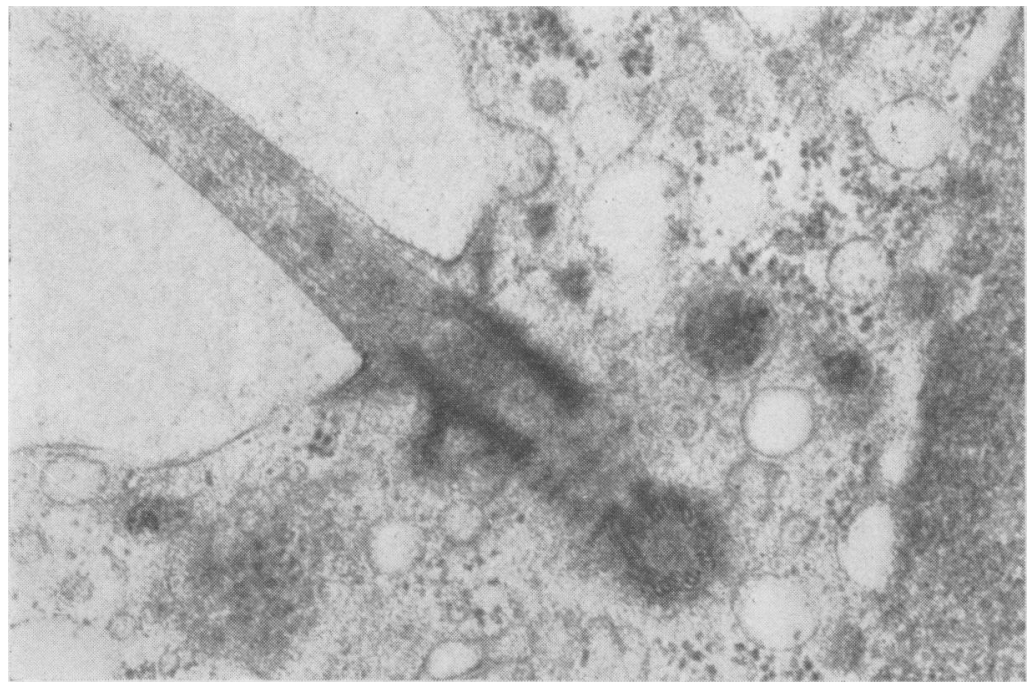

FIG. 4. L.S. of cilium in a zo na glomerulosa cell. $\times 50,000$.

to the satellites: these become wider towards the cell membrane and terminate in a row of very small particles. The membrane at the base of the cilium is unusually thick. We have confirmed Dahl's (1963) report that each of the nine triplets of the basal body sends out a processs to the cell membrane. Sometimes a cluster of vesicles is found around these processes and the same type of vesicle (about 200 A diameter) is not uncommonly scattered throughout the matrix of the whole diplosome region.

The fibres of the cilium arise directly from the centriolar fibres: they are paired but do not usually appear to have side-arms like the $9+2$ cilium fibres. It has been suggested by Dahl (1963) that connexions may be present between the fibre pairs and in our experience there is some evidence of their presence (Fig. 5). We have also confirmed Dahl's report that there is a connexion between the peripheral fibre pairs and the cell membrane. Afzelius (1962) has reported that secondary fibres may also be found, and our studies have sometimes suggested their presence. Dahl (1963) and Allen (1965) reported that fibre rearrangement takes place along the length of the cilium. By serial sectioning of cilia of the rat adrenal cortex we have established that (1) cilia taper considerably for most of their length (Fig. 6a-c) - they can be over $2 \mu$ long; (2) all nine peripheral pairs cannot be accommodated at the periphery as the cilium becomes narrower: a rearrangement of fibres occurs to give patterns of eight or fewer peripheral pairs with one or more pairs of fibres centrally placed to give, for example, an " $8+$

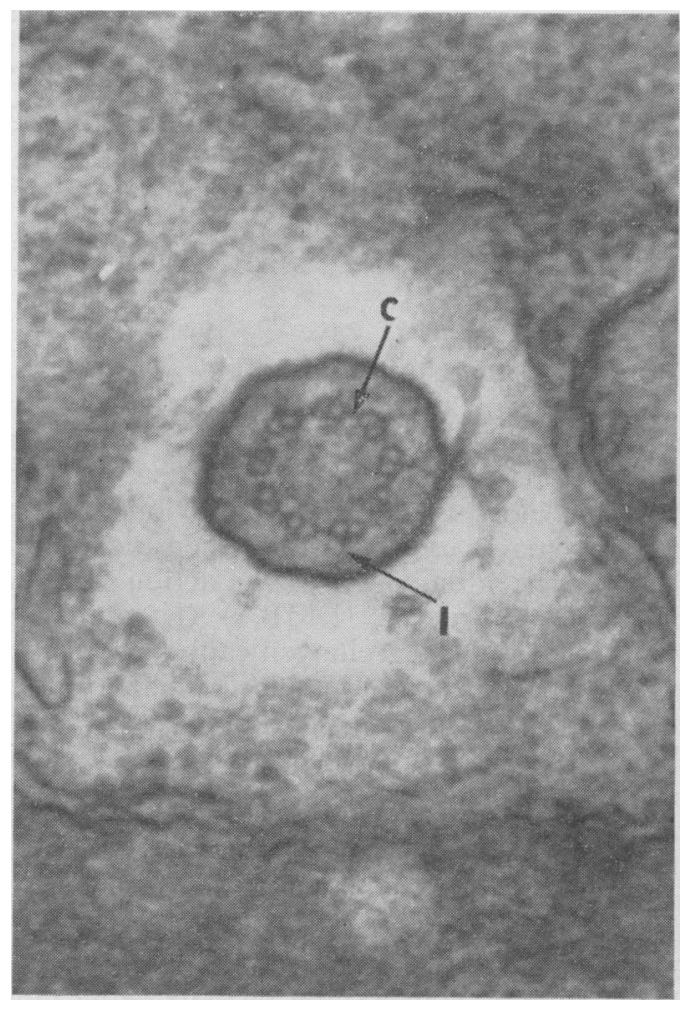

FIG 5.- T.S. of cilium showing $9+0$ fibre arrangement. A connexion between fibre pairs is seen at $\mathrm{C}$ and between a fibre pair and the cell membrane at I. $\times 35,000$. 


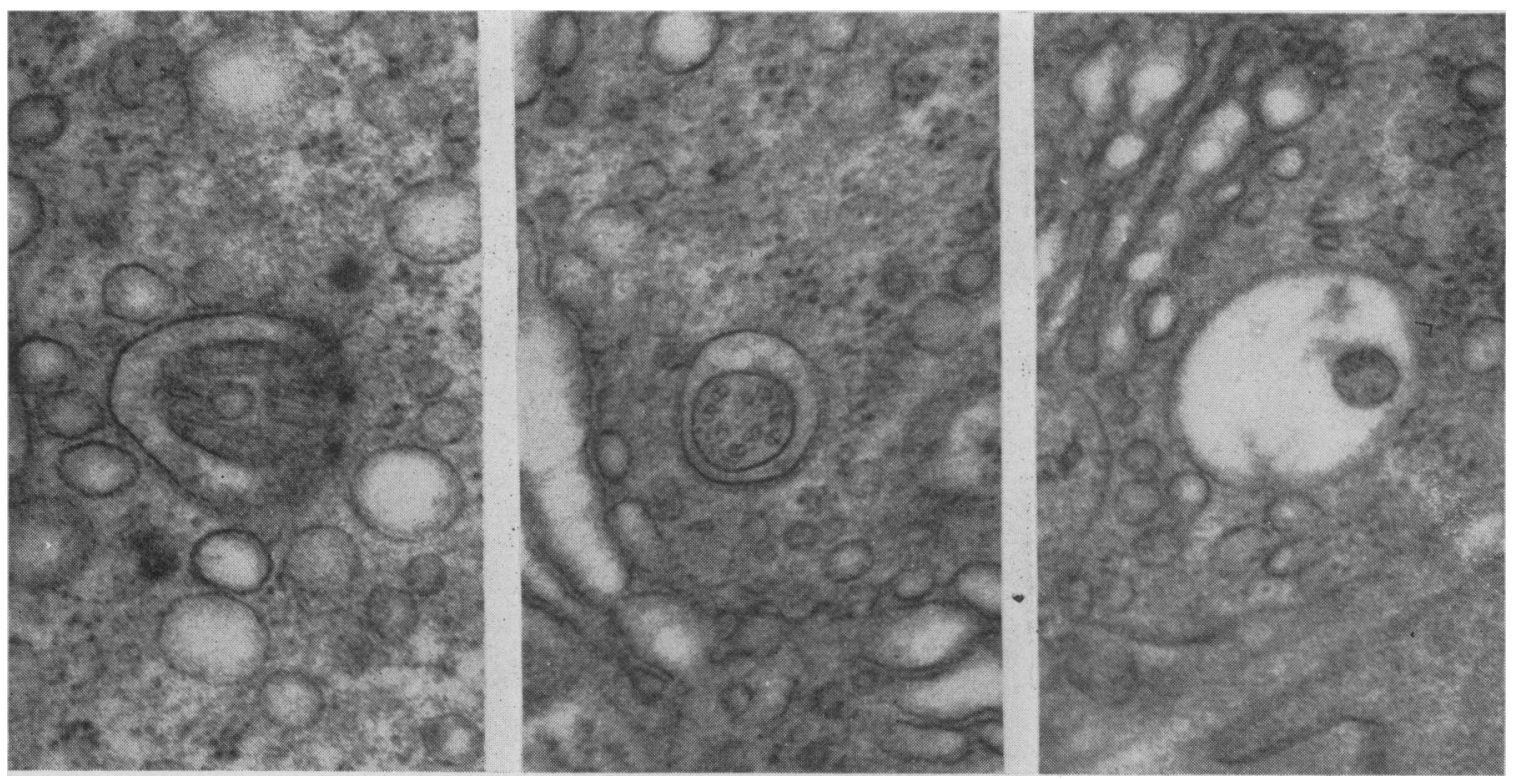

Fig. 6a-c.- T.S. at base (a), in distal region (b) and tip (c) of a serially sectioned cilium. All at same magnification: $-\times 54,000$.

1" or " $7+2$ " arrangement (Fig. 6b); and (3) all fibre pairs do not extend to the tip of a cilium and this probably explains the reports of cilia with less than 9 pairs of fibres (Steiner, Carruthers and Kalifat, 1962; Salazar, 1963; Coupland, 1965).

\section{Cilia in rat zona glomerulosa}

The electron micrographs here used to illustrate the structure of cilia and diplosomes are from the rat adrenal zona glomerulosa, in which they have not been described previously. They are particularly easy to detect when the adrenal gland has been damaged by the action of dimethylbenz(a)anthracene (DMBA) (Huggins and Morii, 1961): this carcinogen causes necrosis of the zona fasciculata and zona reticularis but not of the zona glomerulosa. Some of the zona glomerulosa cells do, however, seem to contain large cytoplasmic vacuoles but by serial sectioning we have shown that in many cases these are continuous with extracellular space and cilia frequently project into them (Fig. 7). Subjectively cilia seem to be more numerous in the DMBA-treated rat adrenal than in the normal gland, but this may be due to their being more easily detected. The zona fasciculata and zona reticularis have been carefully searched for cilia but with negative results: centrioles, which appear to have the characteristics of basal bodies are present but without the ciliary processes (Fig. 8).

\section{Cilia in other tissues}

The tissues in which the $9+0$ cilia with diplosome associations have been previously reported are given in Table 1, and we have now found them in the following cells:

1. Rat zona glomerulosa (Wheatley, 1966a)

2. Mouse zona glomerulosa (Wheatley, 1966a)

3. Rat adenohypophysis (Wheatley, 1966b)

4. Human foetal adenohypophysis (Ellis, 1966)

5. Human foetal epidermis

6. Human foetal cerebral cortex

7. Rat duodenal smooth muscle

\section{Function of $9+0$ cilia}

The extent to which a cilium protrudes into the intercellular space varies from one to another and it seems likely that it is not a rigid passive structure which always bears the same relationship to its cell and the intercellular space: it is probable that it can be protruded or retracted. Its function is unknown but several hypotheses will be briefly discussed.

(1) Sensory function. It was suggested by Munger (1958) and Barnes (1961), largely on the basis that these oilia are found in a number of sensory cells, that they have a sensory function.

(2) Motile function. Coupland (1965) suggested that the cilia "stir up" the intercellular fluid. 


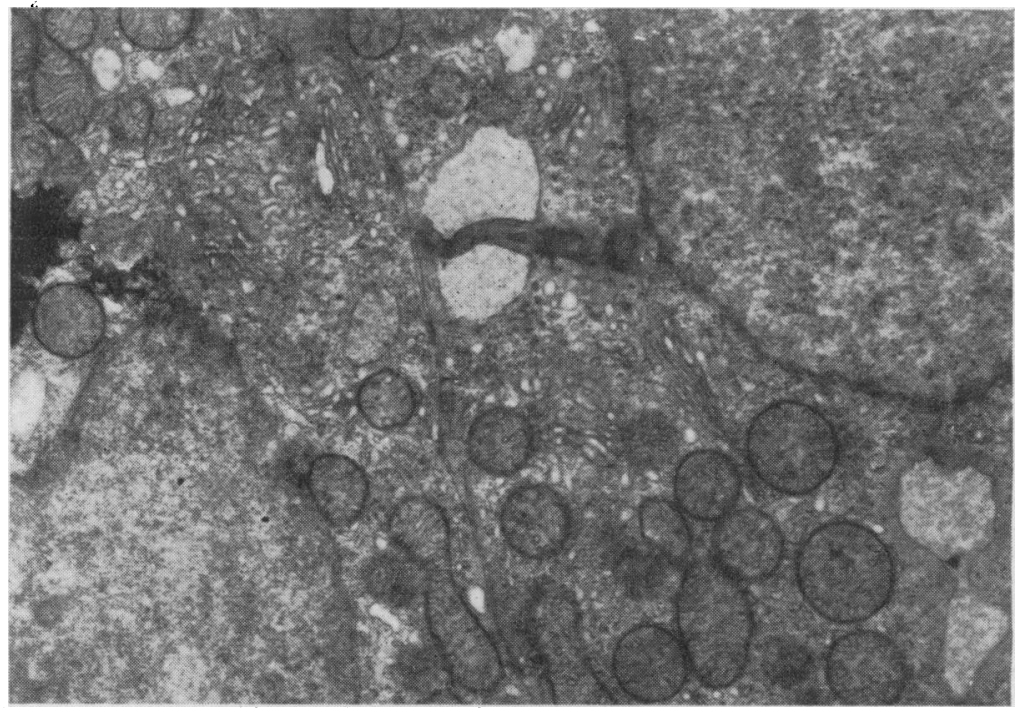

Fig. 7.- Cilium of a zona glomerulosa cell in a vacuole, from an adrenal gland of a rat treated with dimethylbenz(a)anthracene. $\times 12,500$.

(3) Role in mitosis. The association of cilia with the centriolar apparatus raises the possibility that they may be involved in some way in the process of cell division.

(4) Vestigial. The $9+0$ oiliary figure arrangement may be due to incomplete morphogenesis of the $9+2$ form (Sorokin, 1962).

It seems unlikely that the cilia are vestigial and non-functioning since they are present in a number of foetal tissues and their morphology is consistent from cell to cell and from tissue to tissue. Nor does it seem likely that one cilium plays an important motile role. Several questions must be answered before their possible function is defined: for example, it is of importance to determine whether every cell of a tissue possesses a cilium and whether each cell has only one cilium. Dahl (1963) presented some evidence that most of the cells of the fascia dentata in the rat cerebral cortex possess a cilium. Barnes (1961) found an indication of two cilia in a single cell of the mouse adenohypophysis. Some cells of the rat adenohypophysis (Wheatley, 1966b) and of the trabecular endothelium in the human eye (Vegge, 1963) possess two cilia.

We are more inclined to the view that the cilium may have a sensory function. It certainly provides a direct means of communication between the extracellular enviroment and the centriolar apparatus. In view of the latter's role in cell division, the associated cilium may be some delicate control mechanism through which a cell may receive the stimulus to divide. On the other hand, it may be that the cilium determines one pole of a cell before mitosis, the cen-

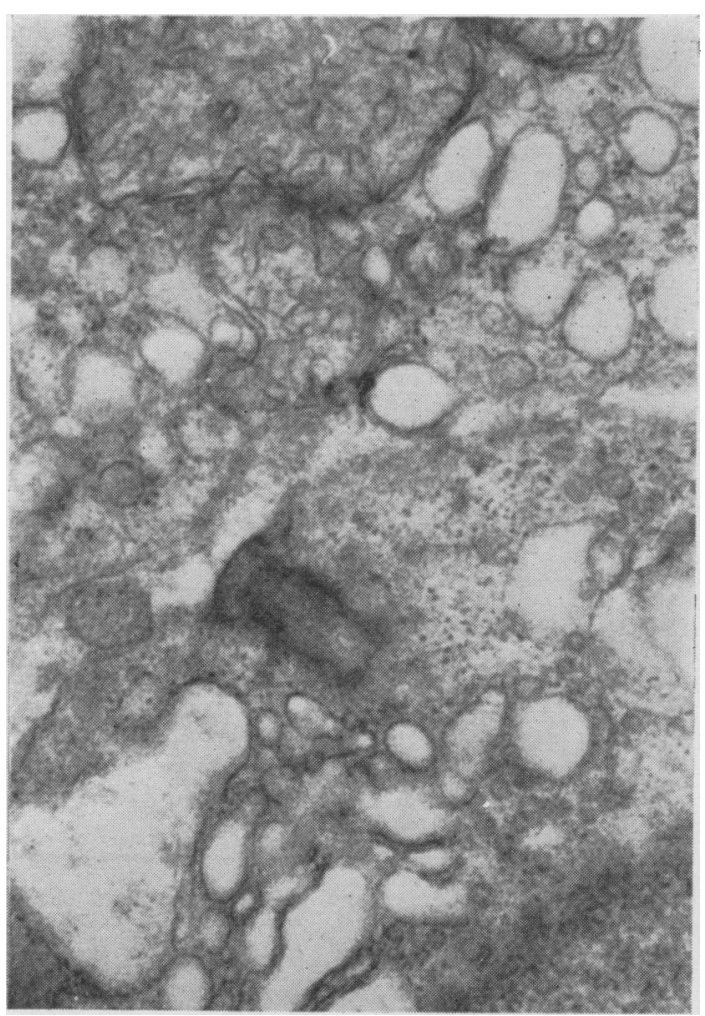

FIG. 8.- Centriole with characteristics of a basal body in a zona reticularis cell. $\times 35,000$. 
triole not associated with a cilium (the proximal centriole) migrating into a diametrically opposite position.

We acknowledge the Scottish Hospital Endowments Research Trust for a grant in part support of this work.

Figs. 2, 4, 5, 6a, 6b and 8 are reproduced by permission of the Editor of $J$. Anat. (Lond.).

\section{REFERENCE $S$}

Afzelius, B. A. (1962): The Contractile Apparatus in Some Invertebrate Muscles and Spermatoza, in Proc. 5th Internat. Cong. Electron Microscopy (Philadelphia, 1962-S. S. Breese, jun., ed.), M-1. New York and London: Academic Press.

Allen, R. A. (1965): Isolated Cilia in Inner Retinal Neurons and in Retinal Pigment Epithelium, J. Ultrastruct. Res., 12, 730.

ANDRE, J. (1961): Sur Quelques Détails Nouvellement Connus de l' ultrastructure des Organites Vibratiles J. Ultrastruct. Res., 5, 86.

Barnes, B. G. (1961): Oiliated Secretory Cells in the Pars Distalis of the Mouse Adenohypophysis, J. Ultrastruct. Res., 5, 453.

Coupland, R. E. (1965): Electron Microscopic Observations on the Structure of the Rat Adrenal Medulla, J. Anat. (Lond.), 99, 231.

DAHL, H. A. (1963): Fine Structure of Cilia in Rat Cerebral Cortex, Z. Zellforsch., 60, 369.

DE RoBertis, E. D. P. (1956): Morphogenesis of the Retinal Rods. An Electron Microscope Study, J. biophys. biochem. Cytol., 2 Suppl., 209.

DE Robertis, E. D. P., Nowinski, W. W., and SAEZ, F. A. (1960): General Cytology, p. 488. Philadelphia: Saunders.

Eisterhuizen, A. C., and Lever, J. D. (1961): Pancreatic Islet Cells in Normal and $\mathrm{Co}, \mathrm{Cl}_{\text {- }}$-treated Guinea-pig. A Fine Structural Study, J. Endocrinol., 23, 243.

Ellis, S. T. (1966): Ph.D. Thesis, Univ. Aberdeen.

GiBBONS, I. R. (1961): The Relationship between the Fine Structure and Direction of Beat in Gill Cilia of a Lamellibranch Mollusc, J. biophys. biochem. Cytol., 11, 179.

GrAY, E. G. (1960): The Fine Structure of the Insect Ear, Phil. Trans. B. 243, 75.

Grillo, M. A., and Palay, S. L. (1963): Ciliated Schwann Cells in the Autonomic Nervous System of the Adult Rat, J. Cell Biol., 16, 430.

Grimstone, A. V. (1962): Cilia and Flagella, Brit. med. Bull., 18, 238.

HuGGINS, C., and MoRII, S. (1961): Selective Adrenal Necrosis and Apoplexy induced by 7, 12-dimethylbenz(a)anthracene, J. Exp. Med., 114, 741.

Kagayama, M. (1955): The Follicular Cells in the Pars Distalis of the Dog Pituitary Gland: an Electron Microscope Study, Endocrinology, 77, 1053.

latta, H., Maunsbach, A. B., and Madden, S. C. (1961): Cilia in Different Segments of the Rat Nephron, J. biophys. biochem. Cytol., 11, 248.
LEeson, T. S. (1962): Electron Microscopy of the Rete Testis of the Rat, Anat. Rec., 144, 57.

MaIllard, M. (1963): Origine des Grains de Sécrétion dans les Cellules de l' antéhypophyse Embryonnaire du Rat; Rôle de l'appareil de Golgi, J. de Mikroscopie, $2,81$.

Miller, W. H. (1958): Derivatives of Cilia in the Distal Sense Cells of the Retina of Pecten, J. biophys. biochem. Cytol., 4, 227.

MUNGer, B. L. (1958): A Light and Electron Microscopic Study of Cellular Differentiation in the Pancreatic Islets of the Mouse, Amer. J. Anat., 103, 275.

Munger, B. L., and Roth, S. I. (1963): The Cytology of the Normal Parathyroid Glands of Man and Virginia Deer, J. Cell Biol, 16, 379.

PitelKA, D. R. (1962): Observations on Normal and Abnormal Cilia in Paramecium, in Proc. 5th Internat. Cong. Electron Microscopy (Philadelphia, 1962 $\rightarrow$ S. S. Breese, jun., ed.). New York and London: Academic Press.

Salazar, H. (1963): The Pars Distalis of the Female Rabbit Hypophysis: an Electron Microscope Study, Anat. Rec., 147, 469.

SATIR, P. (1962): On the Evolutionary Stability of the $9+2$ Pattern, J. Cell Biol., 12, 181.

Slifer, E. H. and Sekron, S. S. (1961): Fine Structure of the Sense Organs on the Antennal Flagellum of the Honey-bee, Apis mellifera linnaeus, $J$. Morph., 109, 351.

SOROKIN, S. (1962): Centrioles and the Formation of Rudimentary Cilia by Fibroblasts and Smooth Muscle Cells, J. Cell Biol., 15, 363.

Steiner, J. W., Carruthers, J. S., and Kalifat, S. R. (1962): The Ductular Cell Reaction of Rat Liver in Extrahepatic Cholestasis. I. Proliferated Biliary Epithelial Cells, Exp. Mol. Pathol., 1, 162.

Tokayasu, K., and Yamada, E. (1960): The Fine Structure of the Retina. V. Abnormal Retinal Rods and their Morphogenesis, J. biophys. biochem. Cytol., 7, 187.

VEGGE, T. (1963): Ultrastructure of Normal Trabecular endothelium, Acta Ophthal. $(K b h), 41,193$.

Wheatley, D. N. (1966a): Cilia and Centrioles of the Rat Adrenal Cortex, J. Anat. (Lond.). In press.

Wheatley, D. N. (1966b): Cells with Two Cilia in the Rat Adenohypophysis. To be published.

Whitear, M. (1960): Chordotonal Organs in Crustacea, Nature, (Lond.) 187, 522.

Wilson, R. B., and McWhorTer, C. A. (1963): Isolated Flagella in Human Skin. Electron Microscopic Observations, Lab. Invest., 12, 242.

ZAMBONI, L., and Westin, B. (1964): The Ultrastructure of the Human Foetal Spleen. I. One Type of Mesenchymal Cell in the Early Stages of Development of the Spleen, J. Ultrastruct. Res., 11, 469. 